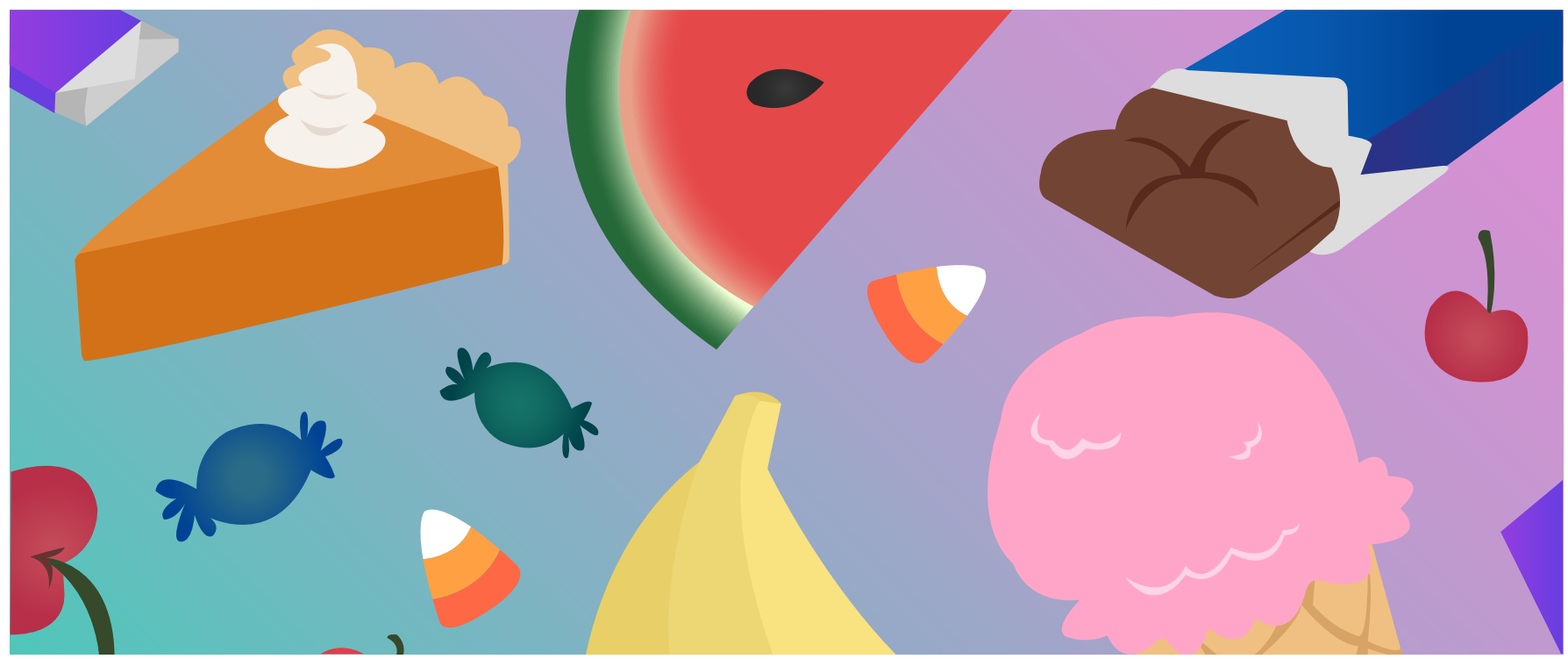

\title{
TREATS AND TRICKS: THE MAGIC WORLD OF SWEETNESS
}

Eleonora Asia Motti' and Piero A. Temussi ${ }^{2,3 *}$

${ }^{1}$ Liceo E. Amaldi, Barcelona, Spain, ${ }^{2}$ Dipartimento di Scienze Chimiche, Universita' di Napoli Federico II, Naples, Italy, ${ }^{3}$ Department of Basic and Clinical Neurosciences, King's College London, London, United Kingdom

\section{REVIEWED BY:}

BRIAN

10 YEARS OLD

ELSA

10 YEARS OLD

YOONSA

9 YEARS OLD
Taste is one of the five senses, together with sight, hearing, smell, and touch. Food contains small particles, molecules, that enter the mouth and are captured by receptors on the tongue, which then tell the brain that their taste is sweet, bitter, sour, salty, or umami (brothy or meaty). Sweet is the taste people prefer, by far. There are thousands of different substances that taste sweet, not only sugar, but many other chemicals, including a few sweet proteins. When the receptor "eats" the sweet molecule, the receptor changes shape and sends a signal inside the cell. Some sweet molecules are really big proteins that cannot enter the cavities of the receptor, but they can also bind to the receptor by hugging it from the outside.

\section{WHEN YOU EAT, YOU BOTH TASTE AND SMELL FOOD}

Humans like food and with good reason. We cannot survive without eating, because food gives us calories and many useful substances that help us stay healthy. The way to choose which food to eat depends on its taste. Taste is one of the five senses: sight, hearing, touch, smell, and taste, all of which allow our 
UMAMI

Umami is the taste typical of broth or meat and of many oriental foods; the word umami comes from Japanese and means delicious. You may also know it from the Pringles chips.

\section{SIGNAL}

An act that serves to start an action.

MOLECULE

The smallest part of a substance containing strongly bound atoms.

\section{RECEPTOR}

A protein on the surface of a cell that "receives" another molecule by binding to it and sending an electrical signal to the brain.

\section{PROTEIN}

A giant molecule made up by joining many amino acids. body to communicate with the external world. Taste is perhaps the sense we are most interested in.

How many different tastes do you think are there? There are so many different kinds of food that it seems obvious that there are many, many tastes. Take fruits: how different is the taste of cherries from that of apples, pears, peaches, grapes, melons, or strawberries? Or think about treats: are all cakes alike? Candies, gingerbread, cookies, toffee, biscuits, doughnuts, buns, chocolate bars: are they all just sweet? Do they taste only like sugar? Surely not.

Judging from personal experience, you probably think that there are many tastes, perhaps as many as there are different foods. But surprisingly, scientists have found that there are only five tastes: sweet, bitter, sour, salty, and umami (meaty or brothy). The complicated tastes of the foods we eat are due in part to the fact that we cannot easily separate smell from taste and, in addition to five tastes, there are hundreds of different odors perceived by the brain. The brain can interpret the combination of smell and taste signals as lots of different kinds of tastes.

\section{HOW DOES YOUR BRAIN RECOGNIZE DIFFERENT TASTY MOLECULES?}

How can we be sure that there are only five different tastes? So far, scientists have discovered only five ways of transmitting taste signals to the brain, corresponding to the five distinct types of tasty molecules that we already mentioned.

By using the language of scientists, we may say that, so far, researchers have only found five distinct types of receptors on the taste cells of the tongue, corresponding to sweet, bitter, salty, sour, and umami tastes [1]. Receptors are proteins on the outside of cells that can bind to molecules from the environment. The taste that most people, not only kids, prefer is by far the sweet taste. So, when do we experience a sweet taste? When a sweet molecule enters the mouth, it reaches the taste buds, special groups of taste cells on the tongue that look like flower buds. Some of these taste cells have only sweet receptors on them. When sweet molecules land on the taste receptor, they make the receptor change shape and send other chemical molecules inside the taste cell. This is shown in Figure 1, where the red balls represent sweet molecules and the receptors are drawn as arrows with two arms on the surface of a taste cell (magenta). After a red ball lands on the receptor, the receptor changes shape, folding its arms, and an electrical signal is transmitted from the taste cell to the brain. It is the brain that will decide that a given electric impulse means "sweet," when we eat a piece of candy, or "bitter," when we take a medicine. 


\section{FIGURE 1}

A taste cell receives sweet stimuli from molecules (represented by the small red balls) that bind to receptors (represented by green arrows with two arms, on the magenta cell shown on the right side of the figure). Upon binding to the sweet molecule, the receptor changes shape, closing the two arms, and when it does this, it sends other molecules inside the cell. In the end, the cell transmits electricity to the brain to tell the brain that it found a sweet molecule.

\section{SACCHARIN}

The first artificial sweetener.

\section{ASPARTAME}

One of most common artificial sweeteners.

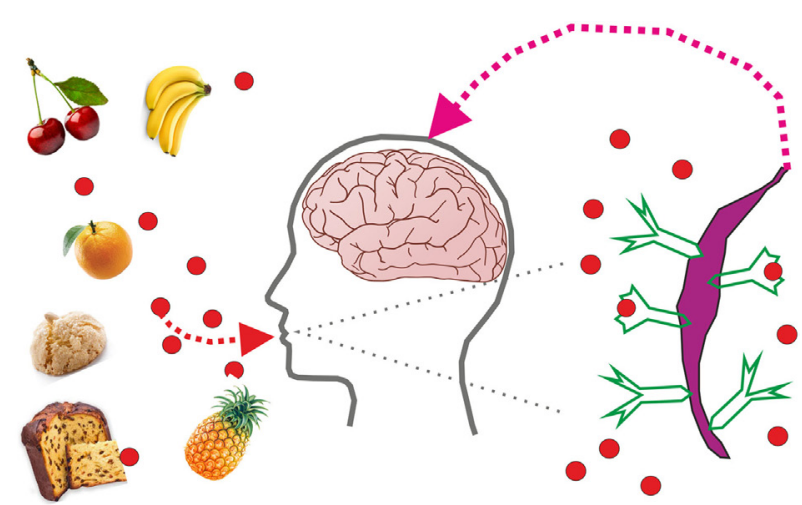

FIGURE 1

\section{WHY ARE SWEET MOLECULES SWEET?}

What makes sweet foods taste sweet? All foods are made up of very small particles, called molecules. Certain molecules in sweet foods can activate the sweet receptors you have seen in Figure 1, which send the brain the message "SWEET."

Which molecules are sweet? When talking about sweet things, the first substance that comes to mind is usually sugar. Certainly, sugar molecules are sweet, but as we already mentioned, sugar is not the only sweet molecule: there are thousands of different substances that taste sweet, and not all of the sweet molecules look alike.

Many of the sweet molecules are sugars like cane sugar, which we all know, or fructose, which is the sugar that is present in many fruits. Other sweet molecules have different chemicals in them and have different shapes. An example is glycine, which is the simplest amino acid, one of the building blocks of proteins. The word glycine comes from the ancient Greek word "glykos," which means sweet. In Figure 2, you can see models of some common sweet molecules with very different shapes. These models are drawn the way chemists used to draw molecules: the atoms are shown as balls glued together to form the molecules. In Figure 2, you can also see pictures of the sources of the various sweet molecules: sugar cane for sugar, wisteria flowers for glycine, various fruits for fructose, and serendipity berries for the sweet protein monellin. (This protein was called monellin after the name of the Monell Chemical Senses Center in Philadelphia, were it was discovered.)

Beside natural sweet molecules that come from plants, there are also many sweet molecules prepared by chemists, like saccharin, which was the first artificial sweetener, and aspartame. Many of these man-made sweet molecules are used to change the taste of food and therefore are called artificial sweeteners. The taste of these molecules was usually found by accident, when some chemist 


\section{FIGURE 2}

Atomic models of some natural sweet molecules: cane sugar, fructose, glycine, and a sweet protein called monellin.

The atoms of carbon, oxygen, and nitrogen, which make up most natural substances, are shown as green, red, and blue balls, respectively. Next to each sugar model, there are images of the plants or fruits where they are found: sugar cane for sugar, several fruits for fructose, serendipity berries for monellin, and wisteria flowers for glycine.

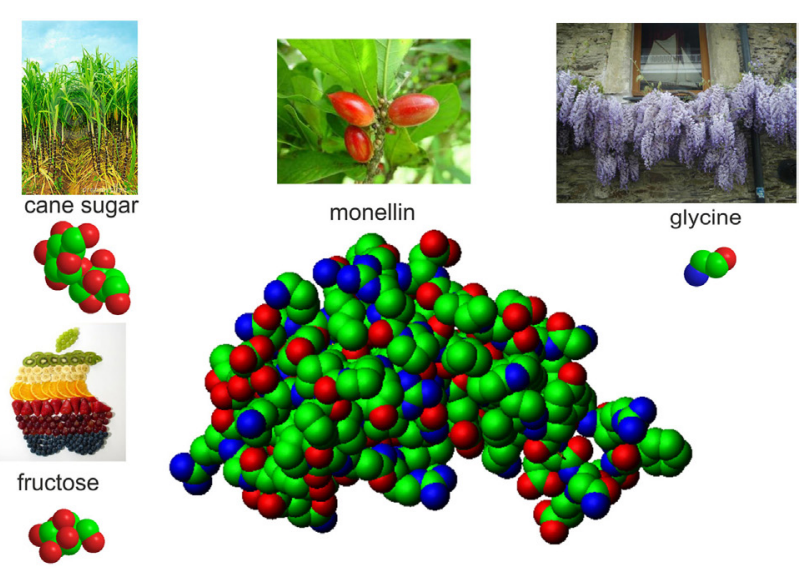

FIGURE 2

did not wash his hands before going to lunch, but also because chemists in the 1800 s were supposed to taste every new compound! This practice is potentially very dangerous, and these days, chemists no longer taste chemicals!

For many years, scientists thought that there had to be specialized receptors in the mouth that were responsible for tasting food, but until a few years ago, nobody had found them. Now, the taste receptors have actually been discovered, and we understand their structure. The sweet receptor is made of two very similar proteins that stick together, shown in Figure 3 as the cartoon with pink and blue parts. The way the sweet receptor works can be understood by comparing it to the carnivorous plant called the Venus fly trap. As illustrated in Figure 3A, the upper part of this plant looks like a big mouth. When an insect enters it, the "mouth" closes and the shape of the plant changes.

Likewise, the upper part of the sweet receptor can "eat" a small sweet molecule, such as sugar or aspartame (represented in the figure as a green ball). As you can see in Figure 3B, when the receptor "eats" the sweet molecule, the receptor changes its shape. The closed shape, shown on the right, can send a chemical signal inside the cell. This chemical signal becomes an electrical signal and is transmitted to the brain, just like we showed in Figure 1.

\section{SWEET PROTEINS BLOCK THE RECEPTOR}

Food has many components, but the most common ingredients are sugars, fats, and proteins. We know what these ingredients taste like: sugars are sweet, fats are greasy, and proteins are meaty (umami). Nobody would ever expect a sugar to taste like meat or fish, nor a protein to taste like sugar. So, it was an amazing surprise when scientists discovered, in some tropical plants, sweet proteins [2]. While most sweet molecules are small, like the ones shown in Figure 3B, proteins, including a few sweet proteins, are much, much biggerthese large molecules are called macromolecules. 


\section{FIGURE 3}

Comparison between the sweet receptor and a

Venus fly trap plant.

A. The carnivorous plant waits with its mouth open; after a worm enters it, the mouth closes. B. In its open form, the receptor mouth is open; after the sweet molecule enters the cavity, like when a worm enters the mouth of the plant, the receptor closes on the sweet molecule and changes its shape.

C. Another mechanism to activate the receptor is to bind to it from the outside. A sweet protein, represented as a green wedge, blocks the receptor, causing it to stay stuck in its closed, active form. Sweet proteins like this are found in tropical plants.
A the carnivorous plant eats a worm
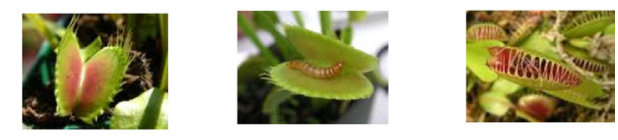

B

the receptor eats a small sweet molecule
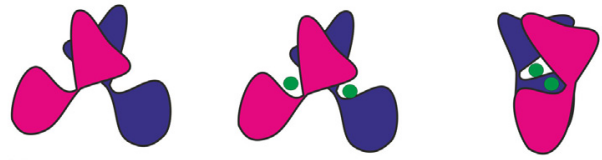

the receptor is blocked by a sweet protein

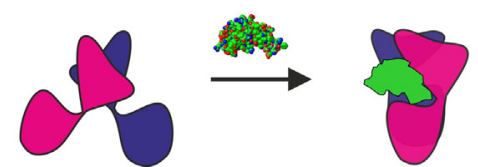

FIGURE 3

The first two sweet proteins discovered, called thaumatin and monellin, are not just slightly sweet but much sweeter than ordinary sugar, up to 100,000 times sweeter. These sweet proteins have many strange properties. For instance, only humans and monkeys think they taste sweet. To other animals, these proteins are tasteless. It is thought that certain berries contain sweet proteins to attract monkeys. The monkeys eat the berries and then spit out the seeds, which can then grow new plants, helping the plants to reproduce.

At first, scientists thought that sweet proteins would bind to a different kind of sweet receptor than the receptors that bind small sweet molecules, because sweet proteins can be almost as big as the receptor, so they cannot enter the small cavities of the receptor the same way the small sweet molecules do (Figure 3). Now we know that there is only one kind of sweet receptor and it can recognize all kinds of sweet molecules, small and big.

How can these huge proteins activate the receptor, since they are too big to enter the cavity of the receptor where small sweet molecules enter and cause the receptor to change shape (Figure $3 \mathrm{~B}$ )? One possible explanation is that large sweet proteins attach to the outside of the receptor, when it is in its closed form. Closed receptors exist in tiny amounts on the cell, together with the open form, even when no sweet substance is around. In Figure 3C, you can see that sweet proteins behave as wedges, because they block the receptor the same way that a doorstop blocks a door from moving [1]. We can say that, instead of "feeding" the receptor, like the small sweet molecules do (Figure 3B), they "hug" it (Figure 3C). 


\section{DIABETES}

A disease that causes a lifelong condition that causes a person's blood sugar level to become too high. If not appropriately treated, it can lead to dramatic symptoms.

\section{OBESITY}

The state of being very fat with relatively little muscles.

\section{CAN SWEET PROTEINS BE USEFUL FOR US?}

Why do scientists study these strange molecules? One of the reasons is just scientific curiosity, but, in the case of sweet proteins, there is also a practical reason. In ancient times, the only way to sweeten food was to add honey. In the 1700s, sugar cane plantations became very common in the Americas and sugar became available to most people at a low price, making kids very happy. However, there is a downside: the excessive use of sugar is partly responsible for many illnesses, like cavities and tooth decay, diabetes (high blood sugar), obesity, and heart problems. Many people who like sweet food try to use artificial sugar substitutes that do not have the high sugar content. But, many artificial sweeteners may be dangerous to human health. That's why scientists keep looking for new sweeteners that are not dangerous. Sweet proteins may be the answer, because not only are they harmless but they are also so much sweeter than common sugar, so that they can be used in really tiny amounts. We hope that, in the future, you will help us to find new molecules that might reduce the risks that come from eating too much sugar.

\section{ACKNOWLEDGMENTS}

We wish to thank Annalisa Pastore (King's College London) and Lucia Leoni (Liceo E. Amaldi) for many very useful suggestions.

\section{REFERENCES}

1. Temussi, P. A. 2009. Sweet, bitter and umami receptors: a complex relationship. Trends Biochem. Sci. 34(6):296-302. doi:10.1016/j.tibs.2009.02.005

2. Cagan, R. H. 1973. Chemostimulatory protein: a new type of taste stimulus. Science 181(4094):32-5. doi:10.1126/science.181.4094.32

SUBMITTED: 06 May 2017; ACCEPTED: 19 July 2017;

PUBLISHED ONLINE: 04 August 2017.

EDITED BY: Fulvio D'Acquisto, Queen Mary University of London, United Kingdom

CITATION: Motti EA and Temussi PA (2017) Treats and Tricks: The Magic World of Sweetness. Front. Young Minds 5:44. doi:10.3389/frym.2017.00044

CONFLICT OF INTEREST STATEMENT: The authors declare that the research was conducted in the absence of any commercial or financial relationships that could be construed as a potential conflict of interest.

COPYRIGHT (C) 2017 Motti and Temussi. This is an open-access article distributed under the terms of the Creative Commons Attribution License (CC BY). The use, distribution or reproduction in other forums is permitted, provided the original author(s) or licensor are credited and that the original publication in this journal is cited, in accordance 


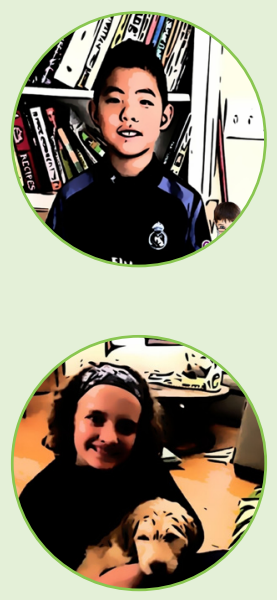

with accepted academic practice. No use, distribution or reproduction is permitted which does not comply with these terms.

\section{REVIEWED BY}

\section{BRIAN, 10 YEARS OLD}

My name is Brian, and I am in the fourth grade. I am 10. I love dogs, playing 2k17, FIFA 17, Battlefront, NHL 16, and RBI baseball 17 on my X-Box. I like playing sports and doing math. I also like Nike and Jordan basketball shoes. I play soccer, basketball, baseball, cello, drums, and piano. I like sports books and comics.

\section{ELSA, 10 YEARS OLD}

My name is Elsa, I am 10 years old, and am interested in language, Medieval and Tudor history, Religion, Genetics, Svalbard, KalaallitNunaat, and Writing. Some of my favorite books include All The Light We Cannot See, by Anthony Doerr, Counting By 7's, by Holly Goldberg Sloan, The Girl Who Drank The Moon, by Kelly Barnhill, and Where'd You Go, Bernadette, by Maria Semple. I decided to start reviewing articles when my friends, Yoonsa and Brian, asked me if I might want to be a part of the peer review process. I agreed because I think that science can be fascinating, and it sounded interesting to be a part of the process involved in getting a scientific article ready to be published.

\section{YOONSA, 9 YEARS OLD}

My name is Yoonsa. I am in fourth grade and I am 9 years old. I live with my parents and my little brother. My parents are both biologists. At our house, we have lots of fish. We are raising baby plecos that hatched from the eggs that I discovered. I wanted to read more about science, so that's why I wanted to join Frontiers for Young Minds. In my free time, I like to read and play the violin.

\section{AUTHORS}

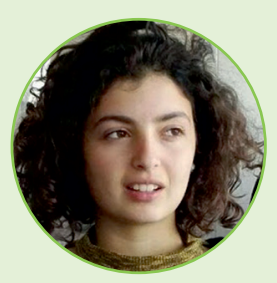

\section{ELEONORA ASIA MOTTI}

Asia is a student of the last year of "LiceoScientifico E. Amaldi," the senior high school that prepares Italian students who want to join science faculties in University. In this Italian school, located in Barcelona, Spain, regular curricula are integrated with foreign languages (Catalan, Spanish, and English). Asia was born in Naples, Italy. Early on, while attending the junior high school (for students between 11 and 14 years of age), she became acutely interested in scientific problems, particularly those related to human senses, the many ways humans interact with the environment. This interest was sparked by a lecture on taste she attended at the end of the third year of junior high school. This article originated from a short stage at the University of Naples when she had the opportunity to discuss with the other author several puzzling aspects of taste, particularly sweet taste. Asia pointed out that most of her fellow students in the junior high school were surprised by the talk she had attended. Thus, the authors decided to illustrate the most interesting aspects of taste. Asia proposed to focus on sweet taste, mainly because it is the most attractive taste for young people. When the first draft was ready, the authors had a second round of discussions to choose whether to concentrate on small sweeteners or on the somewhat exotic topic of sweet proteins. 
Asia's opinion was decisive in favor of sweet proteins. Asia discussed the draft with her fellow students at all relevant stages. Her contributions were not only on strategic choices on the architecture of the manuscript but also on its actual writing and in the design of all figures.

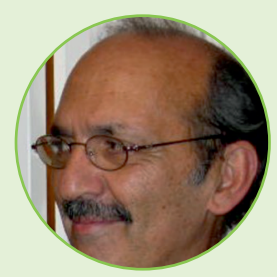

\section{PIERO A. TEMUSSI}

I studied as an organic chemist but, during the following many years, became more and more interested in life science problems, particularly those involving peptides with a biological activity, like enkephalin, the natural substance that our body produces to kill pain. Soon after aspartame was discovered, a friend of mine who is a very good peptide chemist gave me a sample of aspartame to study its structure. Ever since, I have been hooked by the problem of understanding why sweet substances are sweet. *temussi@unina.it 